BUILDING ECONOMICS

appraisal and control of building design cost and efficiency 


\author{
Macmillan Building and Surveying Series \\ Series Editor: IVOR H. SEELEY \\ Emeritus Professor, The Nottingham Trent University
}

Advanced Building Measurement, second edition Ivor H. Seeley

Advanced Valuation Diane Butler and David Richmond

An Introduction to Building Services Christopher A. Howard

Applied Valuation Diane Butler

Asset Valuation Michael Rayner

Building Economics, third edition Ivor $\mathrm{H}$. Seeley

Building Maintenance, second edition Ivor $\mathrm{H}$. Seeley

Building Procurement Alan E. Turner

Building Quantities Explained, fourth edition Ivor H. Seeley

Building Surveys, Reports and Dilapidations Ivor H. Seeley

Building Technology, fourth edition Ivor $\mathrm{H}$. Seeley

Civil Engineering Contract Administration and Control Ivor H. Seeley

Civil Engineering Quantities, fifth edition Ivor H. Seeley

Civil Engineering Specification, second edition Ivor $\mathrm{H}$. Seeley

Computers and Quantity Surveyors Adrian Smith

Contract Planning and Contractual Procedures, second edition

B. Cooke

Contract Planning Case Studies B. Cooke

Design-Build Explained David E. L. Janssens

Development Site Evaluation N. P. Taylor

Environmental Science in Building, second edition R. McMullan

Housing Associations Helen Cope

Housing Management: Changing Practice edited by Christine Davies Information Technology Applications in Commercial Property edited by

Rosemary Feenan and Tim Dixon

Introduction to Valuation D. Richmond

Marketing and Property People Owen Bevan

Principles of Property Investment and Pricing W. D. Fraser

Property Valuation Techniques David Isaac and Terry Steley

Quality Assurance in Building Alan Griffith

Quantity Surveying Practice Ivor H. Seeley

Structural Detailing, second edition P. Newton

Urban Land Economics and Public Policy, fourth edition

P. N. Balchin, J. L. Kieve and G. H. Bull

Urban Renewal - Theory and Practice Chris Couch

1980 JCT Standard Form of Building Contract, second edition

R. F. Fellows

Series Standing Order

If you would like to receive future titles in this series as they are published, you can make use of our standing order facility. To place a standing order please contact your bookseller or, in case of difficulty,write to us at the address below with your name and address and the name of the series. Please state with which title you wish to begin your standing order. (If you live outside the United Kingdom we may not have the rights for your area, in which case we will forward your order to the publisher concerned.)

Customer Services Department, Macmillan Distribution Ltd

Houndmills, Basingstoke, Hampshire RG21 2XS, England 


\title{
BUILDING ECONOMICS
}

appraisal and control of building design cost and efficiency

\author{
IVOR H. SEELEY \\ BSc, MA, PhD, FRICS \\ CEng, FICE, FCIOB, FIH \\ Emeritus Professor of The Nottingham Trent University
}

Third Edition

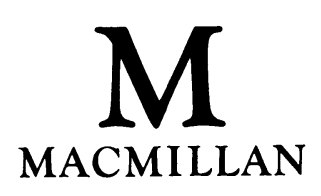




\section{(C) I. H. Seeley 1972, 1976, 1983}

All rights reserved. No reproduction, copy or transmission of this publication may be made without written permission.

No paragraph of this publication may be reproduced, copied or transmitted save with written permission or in accordance with the provisions of the Copyright, Designs and Patents Act 1988, or under the terms of any licence permitting limited copying issued by the Copyright Licensing Agency, 90 Tottenham Court Road, London W1P 9HE.

Any person who does any unauthorised act in relation to this publication may be liable to criminal prosecution and civil claims for damages.

First published 1972 by

THE MACMILLAN PRESS LTD

Houndmills, Basingstoke, Hampshire RG21 2XS

and London

Companies and representatives

throughout the world

ISBN 978-0-333-35039-3

ISBN 978-1-349-17173-6 (eBook)

DOI 10.1007/978-1-349-17173-6

Reprinted 1973, 1974 (twice)

Second edition 1976

Reprinted 1978, 1979, 1981 (twice)

Third edition 1983

Reprinted 1984, 1986, 1987, 1989, 1990, 1993 


\section{PREFACE}

This book critically examines and applies to practical situations the various methods of controlling the cost of buildings at the design stage, which have as their main aim the securing of maximum value for money and a tender which is within the agreed cost limit. In order to implement effective cost control it is necessary to understand fully the various factors which bear upon building prices and to take both present and future costs into account. The subject area thus forms an important facet of quantity surveying, being an activity which is concerned primarily with economic efficiency and value for money.

Tony Brett-Jones has described how quantity surveyors are now able to exercise an important and valuable professional skill in giving independent cost advice, which can be used for budgeting, cost planning and cost control. The quantity surveyor's role, as defined in the RICS report on the future role of the quantity surveyor issued in 1971 and reiterated in Surveying in the Eighties report in 1980 is to ensure that the resources of the construction industry are utilised to the best advantage of society by providing inter alia the financial management for projects and a cost consultancy service to client and designer during the whole construction process. The distinctive competence of the quantity surveyor is a skill in measurement and valuation in the field of construction, in order that such work can be described and the cost and price be forecast, analysed, planned, controlled and accounted for.

As long ago as 1957, the late William James described how the continually rising cost of building, growing at a faster rate than that of manufactured goods, caused clients to feel that the building industry, and its allied professions, were inefficient. In consequence, a building client was inclined to be incredulous of realistic cost forecasts and to require from his professional advisers both an increasing measure of cost explanation and an ever greater attention to cost efficiency in design. Since that time building clients have become more knowledgeable with more sophisticated requirements, and they now demand a much wider range of expert cost advice than quantity surveyors were accustomed to giving in the past. In particular they require an overall appraisal of the alternatives available to them, to enable decisions to be soundly based economically. Hence there has developed a pressing need to refine the tools of cost prediction and control, and for the quantity surveyor to possess a much wider knowledge of factors influencing costs and other related development aspects; this book seeks to meet these needs. It also aims to provide extensive coverage of the final examination requirements of the Royal Institution of Chartered Surveyors (Project Cost Control and Project Development). It will be of assistance to those studying Economic and Quantitative Analysis in the final examinations of the Chartered Institute of Building. It should also prove to be of value to those proceeding to degrees and diplomas in quantity surveying, building economics and building.

In addition, it is felt that the book will be of considerable use to practising quantity surveyors as a handy means of reference, whilst architects, building surveyors, property managers and contractors may find much of interest within its pages.

Metric units have been used throughout. Readers wishing to familiarise themselves with the relative values of metric and imperial measures may find the metric conversion table in appendix 6 helpful. On the drawings, all dimensions in metres are shown with a decimal marker, while all other sets of figures represent millimetres. This procedure eliminates need for the use of the ' $m$ ' and 'mm' symbols for dimensions on drawings.

Economists might argue with some justification that the book is more concerned with building economy than building economics. Nevertheless, the term building economics has been widely used by the quantity surveying profession to describe the investigation of factors influencing building cost, with particular reference to the interaction of building design variables. Furthermore, this study extends much further 
to embrace such matters as the economics of building development, costs in use, land use and value determinants, and environmental economics, and in addition investigates the methods available for controlling building prices.

I. H. SEELEY

Nottingham

Spring 1972

\section{PREFACE TO THIRD EDITION}

Changing economic, technological, social and statutory requirements have made it necessary to rewrite considerable parts of the text. At the same time the opportunity has been taken to generally update the book, omit parts which are of minimal significance, to extend the worked examples and to include information on latest developments and techniques. The section on post-contract cost control has been extended considerably while the costs in use chapter has been widened to encompass energy conservation and life cycle costing. Increased emphasis has also been given to urban renewal. In general the main aim throughout the rewriting was to extend its usefulness to the reader. Unfortunately, fluctuating building prices and interest rates will continue to affect the rates and prices included in the text, which were mainly those operative in mid-1982. Hence these should be taken as guidelines and are used primarily to show the principles and techniques involved. In practice current local rates and prices will need to be used.

I. H. SEELEY

Nottingham

Autumn 1982 


\section{ACKNOWLEDGEMENTS}

The author acknowledges with gratitude the willing cooperation and assistance received from the many organisations and individuals over a period of many years, so many that it is not possible to mention them all individually.

The author has been influenced by the valuable work undertaken by the pioneers in building design cost control techniques and has profited immensely from their investigations. In this connection the names of the late William James, CBE, FRICS, PPCIArb; James Nisbet, FRICS; P. W. Grafton, CBE, PPRICS; and Cyril Sweett, FRICS immediately come to mind. It would also be appropriate to make reference to the valuable groundwork in costs in use carried out by Dr. P. A. Stone. In addition, the author has benefited immeasurably from the work of the Wilderness Group, the BCIS management committee, the Department of Education and Science, Department of Health and Social Security, National Economic Development Council and the Department of the Environment, and has drawn freely from their findings. Valuable information has also been obtained from the RICS journals, Building, the Architects' Journal and the Nationwide Building Society, for which the author is most grateful.

The RICS Building Cost Information Service and Building Maintenance Cost Information Service kindly agreed to the use of cost analyses and other relevant cost information, and the following design teams have also made valuable information available, without which it would have been extremely difficult to have incorporated really meaningful case studies and other relevant cost data.

T. H. Thorpe and Partners, Architects and Quantity Surveyors, 41 Friar Gate, Derby.
White, Cooper and Turner, Architects, 314 High Holborn, London W.C.1.

S. Hardy, Dip.Arch, RIBA, Regional Architect and R. P. H. Brind, FRICS, Chief Quantity Surveyor British Railways Board, York, in collaboration with Turner and Holman, F/FRICS, FCIArb, Chartered Quantity Surveyors, Museum Street, York.

City of New Sarum.

Redditch Development Corporation.

Auburn, Ainsley and Partners, Chartered Quantity Surveyors, Rotherham, Yorkshire.

Edmund Shipway and Partners, Chartered Quantity Surveyors and Cost Consultants, Rodney House, Castle Gate, Nottingham.

The Wood and Weir Partnership, Chartered Quantity Surveyors and Construction Cost Consultants, 5 Wigmore Street, London W1H 9LA.

David Slater Associates, Quantity Surveyors, 58 Otley Street, Skipton.

The author is indebted to the Architects' Journal for permission to reproduce figure 5.4, to the Controller of $\mathrm{Her}$ Majesty's Stationery Office for permission to reproduce figures 5.5 and 5.6 from Flats and Houses 1958 and to Ronald Sears for producing the majority of the final drawings. Finally, grateful thanks are due to the publishers for abundant help and consideration throughout the production of the book, and the advice and comments from members of the staff of the Department of Surveying at Trent Polytechnic proved most helpful, in particular Peter Mitchell, Graham Williams, Donald Treadgold and David Richmond. 
'It is unwise to pay too much; but it is worse to pay too little.' John Ruskin 


\section{CONTENTS}

List of Figures

List of Tables $\quad$ xiii

1 The Concept of Cost Control

Historical development of cost control processes; need for cost control; main aims of cost control; the importance of building; building output and costs; tendering arrangements; comparison of cost planning and approximate estimating; cost control terminology; RICS Cost Research Panel/BCIS Management Committee; cost implications of dimensional co-ordination, examiners' reports.

\section{Cost Implications of Design Variables}

Plan shape; size of building; perimeter/floor area ratios; circulation space; storey heights; total height of buildings; relative costs of flats and houses; implications of variations in the number of storeys of buildings; column spacings; floor spans; floor loadings.

\section{Functional Requirements and Cost Implications of Constructional Methods}

Low and high rise buildings; substructures; structural components; walling; roofs; flooring; doors and windows; finishings; service installations; external works.

4 Influence of Site and Market Conditions and Economics of Prefabrication and Industrialisation

Effect of site conditions on building costs; use of plant; site productivity; market considerations; cost implications of prefabrication and standardisation; industrialised building methods; industrialised housing; problems with industrialised building; economics of industrialised building; the future in industrialised building.

\section{Economics of Residential Development}

Background to public housing provision; use of land for housing purposes; assessment of housing need; dwelling types; housing requirements of occupants; patterns of development to meet varying density requirements; economics of housing layouts; car parking provision; rehabilitation and modernisation of old dwellings; latest trends in housing.

\section{Approximate Estimating}

Purpose and form of approximate estimating techniques; unit method; cube method; superficial or floor area method; storey-enclosure method; approximate quantities; elemental cost analyses; comparative estimates; interpolation method.

\section{Cost Planning Theories and Techniques}

Plan of work; cost control procedure; information required by architect and building client; role of the quantity surveyor during the design stage; cost planning techniques; building industry code; $\mathrm{C1} / \mathrm{SfB}$ classification system; cost planning of mechanical and electrical services; the application of computers to cost control work; cost modelling; cost control during execution of contract.

8 Cost Analyses, Indices and Data

Cost analyses; standard form of cost analysis; cost limits; building cost indices; application and use of cost analyses; cost data; cost research.

\section{Practical Application of Cost Control Techniques}

Worked examples 1,2 and 3 covering the preparation of a preliminary estimate, first cost plan, and cost checks and cost reconciliation during the design process; conclusions; cost control of engineering services. 
10 Valuation Processes

The concept of value and investment; methods of valuation; valuation tables; rental value; premiums; service charges.

11 Costs in Use

Concept of costs in use; cost in use terminology; the technology of maintenance; current and future payments; maintenance and running costs; the lives of buildings and components; practical costs in use examples; energy conservation; prediction errors; effect of taxation and insurance; maintenance cost records; life cycle costing.

12 Land Use and Value Determinants

Changing land use requirements; land use planning; land values; factors influencing development; encumbrances and easements; matters determining land use and value.

\section{Economics of Building Development}

The essence of development; development properties; budgeting for public and private development; land acquisition problems; financial considerations; sources of finance; developer's budget; choice between building lease or purchase.

\section{Environmental Economics}

Concept of environmental economics; public and private investment; structure of the construction industry; variations in workload on the construction industry; relationship of output of construction industry to available resources; effect of government action on the construction industry; urban renewal and town centre redevelopment; new and expanding towns; cost benefit analysis.

Appendix 1 Amount of $£ 1$ table

Appendix 2 Present value of $£ 1$ table

Appendix 3 Amount of $£ 1$ per annum table

Appendix 4 Annual sinking fund table

Appendix 5 Present value of $£ 1$ per annum or years' purchase table 


\section{FIGURES}

1.1 Building cost trends.

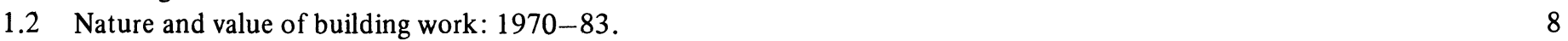

$\begin{array}{lr}2.1 \text { Higher cost of buildings of irregular shape. } & 19\end{array}$

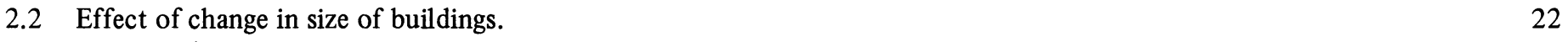

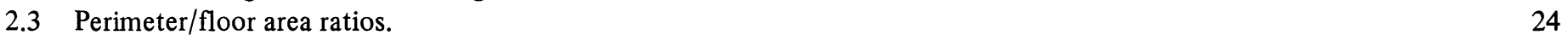

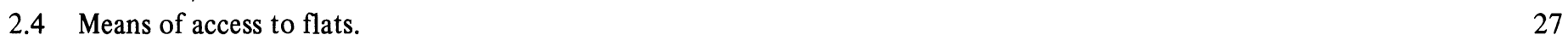

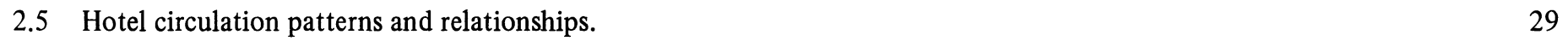

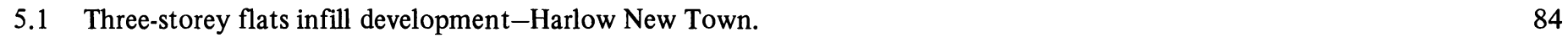

$\begin{array}{lr}5.2 \text { Radburn layout - Cwmbran. } & 85\end{array}$

$\begin{array}{llr}5.3 & \text { Radburn layout - Andover. } & 87\end{array}$

$\begin{array}{llr}5.4 & \text { Residential development-Odham's Walk, Covent Garden. } & 88\end{array}$

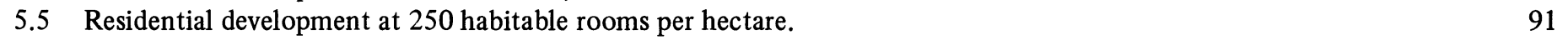

5.6 Residential development at 350 habitable rooms per hectare. $\quad 92$

$\begin{array}{llr}5.7 & \text { Blocks of lock-up garages. } & 94\end{array}$

$\begin{array}{lr}6.1 \text { Approximate estimating - block of six unit factories. } & 104\end{array}$

$\begin{array}{lr}6.2 \text { Office block - estimating by storey-enclosure method. } & 109\end{array}$

$\begin{array}{lr}6.3 \text { Factory check office - approximate quantities. } & 110\end{array}$

\begin{tabular}{ll}
7.1 & Sequence of design team's work. \\
\hline & 122
\end{tabular}

9.1 Cost planning example 2 - three-storey block of flats. 173

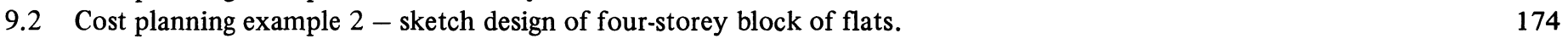

$\begin{array}{lr}9.3 \text { Cost planning example } 3 \text { - social club. } & 187\end{array}$ 


\section{TABLES}

1.1 Labour costs June 1982.

2.1 Effect of shape and height on building costs: total and elemental costs. 20

2.2 Effect of shape and height on building costs: percentage of elemental cost to total cost. 20

2.3 Comparative cost of two-, three- and four-bedroom local authority houses (two-storey). 23

2.4 Proportional costs for four, five and six-person two-storey houses. 23

2.5 Relative proportional costs of local authority houses and flats. 31

2.6 Design cost criteria. 37

3.1 Relative costs of houses and low flats. 39

3.2 Municipal housing - relative substructure costs. 44

3.3 Indices of basement costs complete. 45

3.4 Cost relationships of non-loadbearing partitions. 51

3.5 Comparative costs of alternative coverings to pitched roofs. 53

3.6 Cost relationships of floor finishings. 54

3.7 Cost relationships of internal doors. 54

3.8 Capital costs of domestic heating systems (1982 prices).

3.9 Comparative costs of basic mechanical engineering services. 58

5.1 The maximum cost of modernisation as a percentage of the cost of rebuilding for which modernisation is cheaper. 97

6.1 Comparison of cube, floor area and storey-enclosure approximate estimating methods. 106

6.2 Comparison of cube, floor area and storey-enclosure price rates. 107

6.3 Schedule of comparative costs of different constructional methods. 118

7.1 Plan of work for design team operation. 121

7.2 Cost plan of office block.

7.3 Detailed cost plan of substructural work to school.

7.4 Part of cost study using comparative method. 135

8.1 Concise cost analysis: twelve flats. 145

8.2 Concise cost analysis: warehouse. 148

8.3 Detailed cost analysis: factory units.

8.4 General building cost indices. 155

8.5 Building cost indices for different types of buildings. 156

8.6 Building costs and tender price indices. 157

8.7 Mechanical and electrical cost indices.

8.8 DQSS Index of building tender prices.

8.9 Housing cost index. 158

8.10 Analysis of groups of elements in typical school. 160

8.11 Analysis of housing costs. 160

8.12 Regional factors. 161 
8.13 Average building prices. 168

9.1 Cost planning example 1 - concise cost analysis of factory. 172

9.2 Cost planning example 2 - detailed cost analysis of block of flats. 177

9.3 Cost planning example 2 - initial cost plan: four-storey block of flats, Outer London. 186

9.4 Cost planning example 3 - initial cost plan and record of cost checks of social club. 190

9.5 Suggested procedure for cost control of engineering services in buildings. 194

11.1 Breakdown of costs in use for various types of buildings. 206

11.2 Repairs and maintenance. 207

11.3 Breakdown of total costs. 209

11.4 Types of maintenance. 209

11.5 Breakdown of cleaning costs of a higher education building. 214

11.6 Local authority traditional housing: capitalised maintenance costs as a percentage of initial costs. 217

11.7 Sources and causes of typical local authority housing maintenance costs. 217

11.8 Distribution of maintenance expenditure between different buildings. 217

11.9 Annual equivalent costs in use for typical buildings each providing 100 units of accommodation. 218

11.10 Comparative heating costs. 223

11.11 Comparison of costs of installing and maintaining heating systems. 224

11.12 Relative capital costs of air conditioning plant with different glazing combinations. 225

11.13 Capitalised costs in use for concrete and steel framed flat roofs. 229

11.14 Total capitalised cost of conventional domestic central heating plant. 230

11.15 Effect of errors in predicting lives of buildings. 231

11.16 Average annual maintenance and occupancy costs, 1981.

13.1 House prices in the United Kingdom (first quarter 1982). 252

14.1 British construction output, 1971 to 1984.

14.2 Employment in the construction industry by size of firm in 1978.

14.3 Construction manpower. 268 